\title{
Common Range, Different Tribes: Explaining Resource Use, Management and Productivity among the Akamba, Orma and Somali in the former Eastern Statelands of Kenya
}

\author{
Dickson Mong'are Nyariki ${ }^{1}$ and Jan Van den Abeele $^{2}$ \\ 1. Department of Range Management, University of Nairobi P.O. Box 29053, Nairobi, Kenya \\ Email: range@bidii.com \\ 2. Forestry Development Support Programme, Belgian Technical Cooperation, \\ P.O. Box 30513, Nairobi, Kenya
}

KEYWORDS Common use; range management; resource conflicts; Eastern Statelands; Kenya

\begin{abstract}
This paper describes the major livelihood activities of three ethnic communities who use in common the former Kenyan Eastern Statelands. It also looks at how the livelihoods and the range could be improved while maintaining the common access to resources, so as to avoid potential conflicts. It is suggested that for improvement of range management the unsettled lands should be accessed by all the communities under ranching societies without having to exclude non-members. A number of approaches should be instituted, including bush control and reseeding. Bush control can be achieved through exploitation of trees of low timber value for charcoal production to earn income for households. To increase livestock productivity, it is proposed that proper livestock and grazing management be practised, including the introduction of superior breeds, improved livestock facilities, adequate animal healthcare and rotational grazing through paddocking.
\end{abstract}

\section{INTRODUCTION}

The colonial government in Kenya set aside the former Eastern Statelands for State management. These lands form the interface of the Akamba and Orma lands. Over the years, these lands have provided common wet season grazing ground for the Akamba, Orma and Somali ethnic groups (tribes). They have also provided an important corridor for wildlife. Since independence, efforts towards utilising the lands in various ways have been put in place, mainly as a national reserve and ranching cooperative societies. The latter have, however, largely failed.

The former Statelands are a unique range resource in that they are accessed by three pastoral and agropastoral communities. Where a resource is accessed by more than one individual or community, it is referred to as the commons. Under these conditions, resource use conflicts are a common feature as scarcity of resources and competing users provide a recipe for such conflicts. However, there have been no such conflicts in this case, even though they cannot be ruled out in future.

To avoid potential conflicts, as the common resource continues to diminish in the face of increasing human population and the need to acquire more grazing to enhance food security and improve the living standards of the communities, the stakeholders and development agents should rethink the use and management of this resource. The objective of this study was, therefore, to:

- describe the current state of the range and its management in the former Statelands

- analyse the actual use and occupation of the communities using the lands

- propose appropriate interventions that would improve local livelihoods

\section{STUDY AREA}

The former Eastern Statelands mainly cover parts of Kitui and Mwingi Districts in the Eastern Province of Kenya, about $160 \mathrm{~km}$ east of Nairobi. Both districts have an area of 30,200 sq. $\mathrm{km}$ with a population of about a million people, most of whom are Akamba by ethnicity. The districts belong to two distinct physical regions - the land above 1,000 m falls within the Eastern Highlands of Kenya and that below 1,000 m lies within the low foreland plateau of Kenya (Ojany and Ogendo, 1973). The eastern part of Kitui and Mwingi, within which the fomer Statelands are found, belongs to the latter region. The districts lie in a region that has generally been classified as agro-ecological zone (AEZ) V (Pratt ad Gwynne, 1977), but has several pockets of micro- 
climates of higher potential influenced by differing elevations. The area has a bimodal rainfall regime. The first rains of the year come in March/April (first season) and the second in November/ December (second season). On average the precipitation is $200 \mathrm{~mm}$ for the first season and $300 \mathrm{~mm}$ for the second season. In some areas like Endau Hills of Kitui, rains can be as high as 1,000 $\mathrm{mm}$ in some years. As one moves down-slope, so rainfall diminishes. This precipitation is erratic with frequent general or localised droughts.

Most of the former Eastern Statelands are bushland of Acacia-Commiphora ecological type (Ominde, 1968), with little grass cover. The population density varies with the degree of aridity. The density of the lowlands is low, approximately 12 persons per sq. $\mathrm{km}$ while that in the wetter areas is as high as 228 persons per sq. $\mathrm{km}(\mathrm{ROK}, 1997)$.

\section{METHODS OF STUDY}

Several visits were made to the field to familiarise with the study area and to collect primary data. Data and information involved informal discussions with individual farmers and pastoralists, and barazas (focus group meetings) organised by the local chiefs comprising members of Sosoma and Enziu Cooperative Societies and non-members of the societies utilising both ranch land and the corridors between the national reserves and the ranches, i.e., within the former Statelands.

Discussions with individual farmers and pastoralists centred on the sizes of the households, livestock holdings, grazing areas and seasons of grazing, livestock movements and times of movement, grazing (land) rights, marketing of livestock, animal healthcare, watering points, water availability and use, problems of livestock production and marketing, and issues of access conflicts.

The informal interviews with the management of the ranches included a discussion on the history of the ranches, the objectives set and whether these objectives had been met, livestock production, and range management. For the focus group discussions involving both the farmers and pastoralists, who included the Akamba, Somali and Orma communities and the members and administration of the ranching cooperative societies, the issues were related to the major problems faced in trying to execute the livelihood activities.

In addition to the field visits, relevant literature was reviewed and archive work carried out in government offices in Nairobi, Mwingi and Kitui.

\section{RESOURCE ACCESS ANDLIVELIHOODS}

\section{Livelihoods}

Because of the arid climate, the Akamba, particularly those inhabiting the fringes and parts of the former Statelands, engage in livestock production as their major economic activity. This also applies to their neighbours, the Orma, found on the eastern side of the former Statelands in Tana River District, and the distant Somali from Garissa District. However, the other most important livelihoods are cultivation and labour migration (O'Leary, 1980). The Akamba and the Orma practise agropastoralism, but in different degrees; the former do agriculture more extensively and intensively and rely less on livestock for subsistence than the latter and the Somali who are more 'pure' pastoralists.

Cattle, goats and (to a small extent) sheep are kept by the Akamba. In addition, the Orma and Somali keep camels. The common livestock breeds are the Boran, Zebu and their crosses and Sahiwal-a superior Zebu breed in terms of both meat and milk. The goats include the Galla, Small East African (SEA) and crosses of Galla and Boer. Sheep of Red Maasai and Dorper breeds and their crosses are kept mainly in Mutitu, Kabati, Mutomo and Yatta Divisions of Kitui District, but are rare in most parts of Mwingi District because of a strong belief that eating mutton or keeping sheep reduces one's protection against witchcraft (DRO, Mwingi, Personal communication). In some parts of the districts, such as Central, Yatta and Kabati Divisions (Kitui) and around Mwingi Township (Mwingi District), dairy breeds are kept. These include crosses of Jersey, Sahiwal, Guernsey, Ayrshire and Friesian. Farmers are advised by extension officers to keep exotic breeds in these areas (ROK, 1997). Chicken are also kept in homesteads under a free-ranging system. In the Akamba tradition chicken rearing is a woman's activity (Assistant Chief, Katumbi, Personal communication). Donkeys are kept as beasts of burden, but the Orma and Somali keep camels both for transport and as a source of milk and (rarely) meat. Donkeys are mainly used for carrying water and, since the distances covered 
are long, it has become mandatory for a Mkamba young man to acquire at least one before he can be accepted by a bride-to-be (Assistant Chief, Twambui, Personal communication). Some men also keep a few beehives, producing honey for sale and for making the local brew (Karobo, in Kikamba).

Livestock are the main source of food and income for the three communities. The animals (cattle and goats) provide milk, which is taken fresh and in tea or used to produce ghee. The animals are sold when cash is required to buy grains, pay fees or meet other domestic requirements. The Akamba are more exposed to the cash economy than the Orma and Somali and most raise their animals purely for the market. The traditional strategy of having large herds is no longer viable. As noted by the DRO of Mwingi (cf. also O'Leary, 1980), Mwingi and Kitui Districts are well served with stock markets. The markets are held weekly, and prices depend on supply and demand; they tend to be low in January when livestock are sold to raise money for school fees and during droughts or dry seasons when pastures are scarce and owners are forced to sell, thereby creating a glut. The market system for livestock is also a means through which heifers and young cows circulate from household to household. Nowadays, both the Akamba and Orma cattle owners invest their cattle wealth in some form of non-farm activities such as local stores and trade in livestock. Some have organised themselves into self-help groups (SHGs) that engage in trading in cattle and goats and other non-livestock related activities. These are latterday logical developments in pastoral societies, because 'cattle capital' herded in diminishing rangelands and harsh conditions carries greater risks than investments in enterprises independent of these factors.

Goats are normally sold for requirements that do not need large sums of money while cattle are sold to meet large expenses. Livestock also serve other functions; they are used as bride price and oxen are put to the plough. Goats give birth twice a year and twining is common. Sheep reproduce at a lower rate than goats but faster than cattle.

\section{Access to Range Resources}

\section{Resource Ownership and Use}

Pastures are available both in the home rangelands and the distant grazing grounds in the former Statelands (woiye, in Kikamba). The home grazing grounds consist either of the fenced areas, which belong to households (isesi, in Kikamba), or unfenced communal land. As the name implies, rangelands in the former Statelands belong to the State and in practice are open as pastures to the residents of the lowlands-the Akamba on the western part and Orma on the eastern part. They are also utilised by others from elsewhere, including the upcountry Akamba and the Somali from the distant north-east. Legally, however, the former Statelands have been subdivided, part leased to two cooperative ranches_-Enziu (in Kitui District) and Sosoma (in Mwingi District)-part in two corridors (unallocated) and the rest is used as National Reserves under the county councils. Legally, therefore, the former Statelands under the cooperative ranches are closed to non-members while the National Reserves are nominally available to the surrounding communities for grazing.

Movement of the Akamba livestock takes place from the homelands on the west over the former Statelands to Tana River and back. Likewise, the Orma and Somali livestock move from the east and north-east towards the former Statelands and back. This is depicted diagrammatically in Figure 1. These are transhumant patterns under extensive grazing husbandry, from homelands to former Statelands. As soon as the rains fill the natural pans in March/April and November/ December, which form a network of major water points across the former Statelands, cattle are

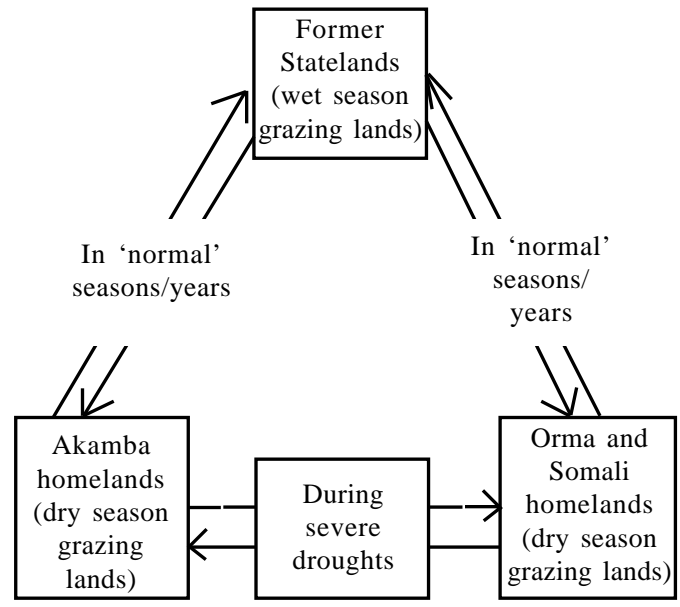

Fig. 1. The Akamba, Orma and Somali livestock movements 
moved to graze there. Herds of several individuals are grazed together as they move from place to place along particular routes that depend on the seasons, which affect pasture availability. In the homelands, except for a few areas where there is paddocking (fencing) and reserved pastures, few efforts have been made to develop a grazing system in the home rangelands. Otherwise animals graze by roaming about. Harvesting of grass is rarely done, except where some animals have been upgraded.

\section{Pastoral Livestock Management and Resource Productivity}

Livestock production in the study area is characterised by low productivity because of various reasons. Chief among these is poor and degraded rangelands, caused by drought and too many animals. Poor management, that does not include such aspects as disease treatment and control, pasture improvements and supplementation, is also a factor. These are, however, as a result of external factors, beyond the control of the pastoralists. Out of experience and in harmony with the environment, pastoralists do practise competent animal management. For example, they allow bullocks to mate in December and April so that cows served in the former month deliver before the beginning of the November/December rains; while those served in April drop their curves towards the end of the November/December rains. This strategy helps to prevent cows calving at the end of the March/April rains, as the long dry season that follows is a stressful period for the newly born calves. Some attempts at range management by government departments and development organisations operating locally, such as GTZ (Food for Work Programme) that is involved in soil conservation, have been made through reseeding trials in a few areas with Eragrostis superba, an abundant grass species. Most of these trials have not been successful, except probably for those in Mui Division. Cenchrus ciliaris, which is a good grass for reseeding, is scarce in the district, the main reason being the low rainfall and overgrazing. There are also losses of animals occasioned by frequent droughts that reduce the availability of pastures and water. Old cattle and calves are most vulnerable to drought, and heifers and dams reduce their calving rates, because of poor physical condition (Dahl and Hjort, 1976). In the absence of any meaningful veterinary care, drought drastically diminishes resistance to diseases; some of the common ones being Footand-Mouth Disease, East Coast Fever, Rinderpest, Contagious Bovine PleuroPneumonia (CBPP), and Contagious Caprine Pleuro-Pneumonia (CCPP). Thus, the former Statelands play a very important role; the effects of drought are ameliorated by those pastoralists who relentlessly travel long distances in search of pastures. During some droughts parts of the former Statelands and home ranges receive some rain. But custom, practice and insecurity sometimes restrict herd movement. Insecurity, as claimed by the Akamba and Orma elders, has in the past been almost exclusively caused by the Somali tribesmen in possession of modern weapons. This problem has, however, currently eased.

\section{Land Management for Cropping}

In their homelands, the Akamba and Orma (the latter to a lesser extent), especially those along riverbanks, practise slash and burn system of cultivation. The Somali are also involved in cultivation to a small extent. Shifting cultivation is dominant. After cultivation and when fertility is low, the area is left fallow, with little or no vegetation cover over a long period of time (as no vegetation can grow on unfertile soils). Whenever burning takes place, mainly on the hills, it is for shifting cultivation. Burning is rarely done for range management to improve pastures. When cultivated areas are left fallow, they are too poor for any plants, including weeds, to grow. Reseeding of pastures is, therefore, not possible under such circumstances.

It is mainly the women who do cultivation, and in the case of the Akamba each married woman has her own garden (see also O'Leary, 1980). The principal subsistence crops are millet, cow-peas, sorghum, Dolicos lablab, and Katumani maize. Green grams are mainly grown for the market. After a good harvest most of the crops are, nevertheless, stored and sold during the next drought. However, the poor will often sell soon after harvest to meet their immediate needs. Drought periods generate sellers' markets for grain and buyers' markets for livestock. Even in favourable market conditions, the sale of surplus food is usually only sufficient for the purchase of small stock (O’Leary, 1980). 


\section{CONFLICT AVOIDANCE, IMPROVING RANGEMANAGEMENT ANDPRODUCTIV- ITYGROWTH}

How can livestock and rangeland management be improved under the conditions discussed above? Because of the land resource tenure and access (by more than one community) prevailing in the study area, optimum conditions for the Akamba, Orma and Somali herd growth can only be achieved through seasonal grazing of the former Stateland pastures (cf. O'Leary, 1980). While it is important to recognise land ownership status, at least legally, when considering the appropriate interventions, one must look at the former Statelands as a unit rather than as separate entities belonging to cooperatives, national reserves and corridors. Thus the key to success in herding in the former Statelands is to find a grazing system, which connects sites with good forage to water. The focus should be on the settled areas on the fringes and inside former Statelands.

\section{Ranching Societies}

The two cooperative ranches-Sosoma and Enziu-were established in 1985 on the former Statelands with a leasehold title of 45 years. Cooperative ranches are formed by groups of people who agree to form a society under the Societies Act (Cap. 490, Laws of Kenya) and raise funds to purchase shares or a ranch or group of ranches. Sometimes county councils may allocate land to cooperatives for a stated period (Nyariki, 1990). The cooperative movement was encouraged in Kenya to create conditions of economies of scale in order to enable farmers or livestock producers to acquire credit and inputs, and surplus products. However, the performance of cooperatives has declined in the 1990s due to mismanagement, political interference, stakeholder disputes, inadequate professionalism, and lack of group dynamic skills.

In general, the performance of ranches in Kenya has not been impressive. A study carried out by Onchoke (1986) on the impact of cooperative, group and individual ranching systems on resource productivity in central Kenya gave a significantly negative value for net returns per capita, hectare and animal unit for the individual and cooperative ranching systems.

Group ranches were initially established in
Maasailand (Kaputiei Section) in accordance with the Land (Group Representatives) Act (Cap. 287, Laws of Kenya), commenced on $28^{\text {th }}$ June, 1968. They were later adopted in other arid and semiarid areas. This concept of ranching has failed mainly because of managerial problems related to their design. Their main feature is that land is used communally (under communal land rights) but herds are owned individually. Under this arrangement members do not individually have direct responsibility for managing the rangeland or the maintenance of ranch facilities.

Households flanking both sides of the former Statelands have herd and flock sizes ranging from zero to 80 head of cattle and zero to 100 goats respectively. The difference in the sizes of household herds and flocks forms the basis for cooperation in herding and exchanges between households. This is of significance to range planning. The establishment of cooperative ranching often benefits large and medium herd owners, who can afford to risk becoming shareholders in the ranches. This transfers the decision on those to be employed in herding and other ranch activities from the community to ranch officials, often people from outside the immediate community, and committee members who serve the interests of richer and influential households and local politicians. All these happened in both Sosoma and Enziu. Cooperative ranching has accelerated the increasing gap between the poor and the rich and land degradation.

Both Sosoma and Enziu Cooperative ranches in the former Statelands have failed because of several reasons. The failure of Enziu ranch is attributed to the inadequacy of water, low quality management, corruption, and insecurity. Like Enziu, Sosoma ranch has neither a perimeter fence nor paddocks. It is situated in a slightly drier area, bush encroachment is heavier and grass availability is much less. The problems faced by the ranch are almost similar to those of Enziu except that land use disputes between the members and non-members on the one hand and between the Akamba and the Orma (and sometimes the Somali) on the other seem to be more pronounced here. Thus, the potential use rights conflicts between the members and nonmembers, on the one hand, and between the Akamba and the Orma or Somali, on the other, are high and must be dealt with if any development of the rangeland in the former Statelands is to succeed. 


\section{Operational Design}

The positive aspect about cooperative ranches is that overgrazing and overstocking can be readily controlled as can the excessive accumulation of stock by individual households. However, most of these checks are in place in the traditional modes of livestock management and ownership. Some of these are dispersal by inheritance and conversion of stock wealth into stores. It will take skill and industry rather than privileged access to grazing and water for optimum livestock production and range management to be achieved in the former Statelands.

Because of their management design, cooperative ranches confine their demarcated range to the stock of members, keep membership restricted, and maintain privileged havens for their members. Membership is also restricted to those who can pay for it, i.e., those with large herds. The problem with this arrangement in an area like the one under study is that it rigidifies the pattern of stratification and is ecologically not viable. It is designed to turn what are essentially seasonal grazing lands into permanent grazing grounds, because they do not incorporate the dry season homeland grazing of the neighbourhoods (as depicted in Figure 1). Thus, unless free movement between the ranches and the homelands are permitted losses of livestock will not be avoided during droughts or dry seasons.

\section{Livestock Production in Societies and Settled Areas}

Since Sosoma ranch is mainly in a bushed area, the most appropriate livestock to be kept is the goat, which is mainly a browser; while Enziu ranch can accommodate both goats and cattle as there are scattered areas of grass cover together with bushland. Goat ranching and probably a few hundreds of cattle in Sosoma will utilise the abundant Acacia bushes and other vegetation. The goat has been blamed for destroying the range out of ignorance, and may not be a friend to a forester. But the main problem is that the goat has the ability to survive in some of the most difficult range conditions, and is therefore found in denuded rangelands long after most of the other livestock have left or died (Pratt and Gwynne, 1977, p.163). It is therefore not necessarily the cause of denudation.

The ranch livestock will have to stay in the ranches all year round, while the livestock belonging to the communities will come in during the wet season. These livestock will use the range both as a wet and dry season grazing. This will, therefore, require provision of extra water and reserve grazing. Distances to water points should be reduced to enhance production. To avoid denudation, it will be necessary that stocking rates are kept low to accommodate the ranch and community herds.

Goat ranching should be given priority for three reasons:

- Unlike cattle, goats are mainly browsers particularly in habitats which are dominated by bush cover. The promotion of goat production in Eastern Kitui and Mwingi will utilise the many species of bush and trees, which cattle can do only to a limited extent. The rangeland in its present state in Sosoma is almost worthless for cattle production but an excellent habitat for goats.

- Offtake rates in goats are much higher than in cattle.

- There is a high demand for improved goats in and outside Kitui District (cf. Njoka, 1983). In most of Kitui and Mwingi Districts, the layer of grass cover is completely denuded except for some parts of Eastern Divisions (former Statelands), which are without year round water availability. The cost of vegetation conversion from bushland to mosaic bush grassland is prohibitive. Hence keeping goats, which can perform well on diets that are initially predominantly browse, will be the most rational livestock development approach.

The demand for goat meat in the domestic market is high and this will increase as human population goes up. It is likely that soon demand will outstrip supply by far, as more marginal lands are cultivated due to rising human population. Goat marketing is more advanced than cattle marketing following the collapse of the Kenya Meat Commission (KMC) and because of the ease of transport and the high demand for goat meat. There are usually large trucks transporting goats from Kitui and Mwingi to as far as Mombasa where demand is known to be high. Thus markets for goats are not limited in the two districts (DRO, Mwingi, Personal communication). What is required is to develop adequate market information systems to reduce the exploitative excess margins realised by middlemen.

As already noted, cattle are kept under traditional management by the three comm- 
unities. There is not much genetic or management improvement. Government programmes have been geared towards disease control programmes such as tick control and vaccination. And even these have not performed well. For example, most of the established dips have fallen into disrepair.

Historically, range degradation in Ukambani and other arid or semi-arid districts has largely been due to excess stocking rates. Although cattle are mainly grazers, they are known to browse in areas where grass cover has been denuded. Large numbers of the cattle in most of Kitui and Mwingi, for example, depend mainly on browse forage (Njoka, 1983). However, cattle will continue to be an important component of the economy of those who continue depending on former Statelands to provide wet season grazing.

In the settled fringes of the former Statelands, a number of cattle improvement programmes are possible. They include the introduction of dairy cattle, animal heathcare, and development of cattle markets.

The best breed for the settled areas close to the former Statelands is the Sahiwal, which can withstand some degree of climatic stress that prevails. The advantages of introducing dairy cattle in the settled areas are to:

- encourage agropastoralists to reduce unproductive cattle numbers in favour of a few productive ones, in turn enhancing soil conservation

- derive complementary benefits accruing from an integrated livestock cropping system, such as manure for crops and crop aftermath (fodder) for cattle (cf. Nyariki and Wiggins, 1999)

- achieve milk self-sufficiency and improved food security

The current low numbers of dairy cattle are attributed to lack of water and scarcity of feeds. But not much effort has been made to develop rainwater harvesting techniques. Most of the households depend on water drawn from sand wells in the beds of seasonal rivers. Few farmers have water tanks. The innovation of new water harvesting techniques will improve water availability for both domestic use and for dairy production.

The constraint of feed availability can be reduced by increased integration of animal husbandry with cropping. A dairy cow is estimated to require 6.5 tonnes of dry matter intake per year. The fodder yield from one acre of planted
Napier grass can range from $8-10,000 \mathrm{~kg}$, while crop residues can yield another $2,000 \mathrm{~kg}$ per acre (Njoka, 1983). The only doubt is whether this fodder yield can be sustained because of the low and unreliable rains.

It is important to improve animal healthcare if improved production of animals for both meat and milk is to be expected in the settled areas and the ranches. Currently, most of the dips for tick control have been abandoned because of lack of water, acaricides, and mismanagement by dip committees. There are high risks of disease transmission as Akamba and Orma or Somali livestock move to the former Statelands from the west and the east. So high grade cattle will easily succumb to disease; and therefore disease control and treatment need to be enhanced. The best option would be to confine the high-grade cattle in a zero-grazing system. This is possible in the settled areas, though difficult because of scarcity of feed resources that would require that some degree of mobility is allowed. Training Community Animal Healthcare Workers (CAHCWs) would also enhance disease control. The introduction of at least two dips in the ranches, placed at strategic points to enhance grazing/range management is an alternative too.

Conventional approaches to livestock production include the improvement of markets as a means of motivating producers. Regular cattle sales are organised in many trading centres, even though not many animals are sold through these centres, likely because of the county council cess charges. In pastoral areas, efforts to encourage offtake by providing marketing channels have largely failed. This may be linked to some herders' disinclination to generate income beyond that required for meeting household requirements. To enhance marketing, SHGs could be used as entry points to understand marketing constraints and how they should be reduced or removed.

\section{Rangeland Management}

The current range condition in the former Statelands can generally be described as poor. There is serious bush encroachment dominated by Acacia-Commiphora vegetation association, with little or no ground cover. Most of the range requires one or other kind of rehabilitation if animal production and productivity is to be improved. Large-scale rehabilitation is almost impossible and can only be justified on the assumption that proper use of rehabilitated lands 
will be observed by the users. Otherwise this is unlikely to be justified economically. In the past, substantial work has been done in the rehabilitation of rangelands, especially in Machakos (Aldev, 1962) and Kitui (current Kitui and Mwingi) (Jordan, 1957; Aldev, 1962), and any attempts at rehabilitation will have to use the research findings as a starting point.

The best place to try wide-scale rehabilitation is where some degree of management control could be in place, such as reorganised cooperative ranches. Some of the range rehabilitation approaches would include bush control, grazing management, and improvement of denuded grazing areas and abandoned cultivated lands.

There are three types of bush problems in the study area. These are impenetrable bush, bushland with low quality herbaceous layer, and sparse bush. The first two are best handled through bush control approaches while the last one is best dealt with through range improvements such as grazing management and improvement of denuded areas.

\section{Bush control}

The proportion of bush to grass in a natural rangeland ecosystem is maintained through both grazing animals and natural fires. The proper number of grazing animals maintains the grasslands in vigorous condition while natural fires control bush encroachment when the grazing animal exceeds the physiological tolerance of natural perennial grasses. These grasses decrease in vigour and through many years of overgrazing the grass cover is denuded. The reduced grass forage in turn reduces the fuel for natural range fires (Pratt and Gwynne, 1977).

The objectives of bush control would be to increase the range productivity for grazing resources (grass and browse), to evaluate bush utilisation measures which are consistent with range conservation objectives, and to demonstrate and test the most cost-effective bush control methods. There might be need to test the various bush control methods to evaluate their usefulness. These methods should include prescribed burning, hand clearing and biological control using goats. This would be done by establishing pilot bush control plots in the settled areas, Sosoma and Enziu.

Other than the amount of money that will have to be invested, large-scale bush control through hand clearing requires enormous labour and may not be practical. What needs to be effected is a control programme at a small-scale. This should try to reverse the ecological balance to what it was before overgrazing occurred.

Burning of charcoal using the excessive trees of relatively low value as timber-such as the Commiphora and some Acacia spp.- - is another means of reducing the bush problem. This does not only control bush but serves as a source of income for the local population.

\section{Grazing Management}

A rest-rotation grazing system in combination with careful use of fire restores the grass cover in almost denuded areas. It also maintains an optimum balance between bush and grass species (cf. Heady, 1960). This could be experimented in the cooperative ranches and some of the fenced rangelands. This type of rehabilitation is likely to be cost-effective for rangelands with an abundance of perennial grasses of $5-10 \%$.

\section{Improvement of Denuded Areas}

Areas that are completely denuded will not benefit from rest-rotation grazing system. They will not recuperate fast enough on their own either, without some form of intervention (Pratt, 1963). These areas include denuded bushlands, abandoned cultivated rangelands, and rangelands under cultivation.

Reseeding denuded bushlands is too expensive. A rational approach is to keep the natural bush cover, unless inaccessible to livestock. The main objective in reclaiming these areas is to include fodder shrubs to upgrade the quality of browse. Grass cover can, however, be established along the erosion gulleys to stop further gulley expansion.

Cultivation loosens the top soil and prepares a good seedbed for reseeding. Where the top soil has not been washed off, broadcasting of indigenous perennial grasses would improve pastures. This would be particularly economically viable in the areas where high yielding dairy cattle are kept. Manure can be easily applied and reseeding of fallow fields done with appropriate (locally found and low-moisture demanding) grass species, such as Eragrostis superba, Cenchrus ciliaris, Panicum maximum, Enteropogon macrostachyus, and Panicum maximum. 
The fallow fields can serve as excellent seedbeds. Seed harvesting from the nearby Tsavo National Park and other protected areas can initially be carried out, but seed multiplication within the districts should be started as well.

\section{CONCLUSION}

The former Eastern Statelands are accessed by three communities as a common wet season grazing resource. This is a unique range resource, even in a pastoral context, because the usual scenario is where only one community utilises grazing in common. Where a resource is accessed by more than one community, resource use conflicts are a common feature as scarcity of resources and competing users provide a recipe for such conflicts. The main reason for the existence of harmony or few conflicts is that the Eastern Statelands were neither allocated to a particular community nor to individuals; they were under State management.

To avoid potential conflicts, as the common resource continues to diminish in the face of increasing human population and the need to acquire more grazing, its use must be carefully planned and made more productive. This can be done in two main ways-improved range management and livestock productivity. Both proper range management and superior livestock production can be achieved by bringing the users together to form ranching societies so that management can be instituted in an organised manner, but at the same time finding ways of not excluding those who may not wish to be members of these societies. The former Statelands should never be closed to any of the communities without providing alternative wet season grazing or some other form of livelihood, as this would carry a high risk of creating tribal conflicts.

\section{REFERENCES}

Aldev. 1962. African land development in Kenya (19461962). Government Printer.

Dahl, G. and A. Hjort. 1976. Having Herds: Pastoral Herd Growth and Household Economy. Studies in Social Anthropology, Department of Social Anthropology, University of Stockholm, Stockholm.

FAO/UNDP, 1973. Rangeland surveys, Kenya: Range development in Tana River District. Working Paper 12 (AGP: SF/KEN 66/511). FAO/UNDP, Nairobi.

Heady, H.F. 1960. Range Management in East Africa. Government Printer.

Jordan, S.M. 1957. "Reclamation and pasture management in the semi-arid areas of Kitui District, Kenya." East African Agricultural and Forestry Journal, 23: 84-88.

Njoka, T.J. 1983. Range and livestock development proposal. Kitui District Focus Plan, ASAL Project, Nairobi.

Nyariki, D.M. and S. Wiggins. 1999. "Livestock as capital and a tool for ex-ante and ex-post management of food insecurity in semi-traditional agropastoral societies: An example from south-east Kenya." Journal of Social Sciences, 3(3): 117-126.

Nyariki, D.M. 1990. Economic Analysis of Beef Ranching: The Case of Laikipia District, Kenya. Unpublished M.Sc. thesis, University of Nairobi, Nairobi.

O'Leary, M.F. 1980. The growth and decline of household herds in eastern Kitui, Kenya. Ethnos, 45(3-4): 211229

Ojany, F.F. and R.B. Ogendo. 1973. Kenya: A Study in Physical and Human Geography. Longman.

Ominde, S.H. 1968. Land and Population Movements in Kenya. Heinemann.

Onchoke, S.N. 1986. The Impact of Cooperative, Group and Individual Ranching Systems on Resource Productivity in South-Central Kenya. Unpublished M.Sc. thesis, Texas A \& M University, Texas.

Pratt, D.J. and M.D. Gwynne, (Eds.). 1977. Rangeland Management and Ecology in East Africa. London: Hodder and Staphton.

Pratt, D.J. 1963. "Reseeding denuded land in Baringo District in Kenya." East African Agricultural and Forestry Journal, 29: 78-91.

ROK, 1968. Land (Group Representatives) Act (Cap. 287, Laws of Kenya). Nairobi: Government Printer.

ROK, 1997. Kitui District Development Plan 1997-2001. Government Printer. 